\title{
Kajian Pengambilan Keputusan Desain dalam Perancangan Rumah Tinggal
}

\author{
Wanda Yovita ${ }^{1}$ \\ 1. Arsitektur, Fakultas Teknik dan Desain, Institut Teknologi Sains Bandung, Deltamas, Indonesia
}

\begin{abstract}
Abstrak
Penelitian ini bertujuan mengetahui atribut desain yang paling mempengaruhi keputusan penghuni dalam desain bangunan rumah tinggal. Atribut desain yang ditawarkan kepada responden adalah posisi atau layout ruang, jumlah ruangan, luas ruangan, tampak bangunan, material, fitur utilitas hingga gaya bangunan. Penelitian ini didasari oleh banyaknya wariabel desain pada rumah tinggal. Kabupaten Bekasi merupakan wilayah yang memiliki banyak jumlah perumahan massal yang diproduksi oleh pengembang. Pilihan dalam atribut desain tidak menjadi keutamaan karena kebutuhan terhadap lokasi dan harga menjadi prioritas utama.

Penelitian ini melihat preferensi masyarakat khususnya Kabupaten Bekasi terhadap atribut desain. Survei berupa sebaran kuesioner dilakukan terhadap 150 masyarakat yang tersebar di Kabupaten Bekasi. Metode analisis yang dilakukan adalah distribusi frekuensi kelompok mesyarakat tertentu di wilayah yang sama terhadap atribut desain.

Berdasarkan informasi yang diperoleh, ditemukan bahwa masyarakat lebih mengutamakan posisi atau layout ruang tertentu dibandingkan jumlah ruangan, luas ruangan dan lain-lain. Penelitian ini selanjutnya dapat dikembangkan untuk memperkaya pengetahuan desain rumah tinggal yang inovatif dari desain dan tetap mempertahankan anggaran. Secara keilmuan, penelitian ini memberikan sumbangan terhadap pengkayaan keilmuan penyediaan perumahan, sedangkan dari sisi praksis, penelitian ini diharapkan akan memberikan pengetahuan solusi alternatif penyediaan perumahan yang tepat sasaran.
\end{abstract}

Kata-kunci: preferensi, atribut desain, arsitektur, rumah tinggal

\section{PENDAhuluan}

Variabel utama yang dipilih oleh masyarakat dalam menentukan rumah tinggal adalah lokasi. Keberadaan lokasi mempengaruhi harga atau kemampuan konsumen dalam membayar ${ }^{1)}$. Dalam mesin pencarian properti daring, lokasi, luas bangunan dan tanah, status kepemilikan dan harga menjadi kata kunci utama. Pertimbangan arsitektur lainnya tidak menjadi prioritas pada mesin pencarian ini. Penelitian ini mempertimbangkan preferensi masyarakat umum dalam keputusan desain bangunan rumah tinggalnya. 
Penelitian ini bertujuan mengetahui pertimbangan penghuni rumah tinggal jika membeli bangunan yang sudah ada ataupun membangun bangunan baru.

Kriteria penting yang menjadi aspirasi konsumen perumahan dalam menentukan perumahan yang diinginkan, berkaitan dengan faktor kemampuan biaya ekonomi, lokasi, kualitas lingkungan dan status sosial dengan lingkungan tetangga ${ }^{2)}$. Ada keterkaitan antara kebutuhan perumahan dengan kondisi sosial dan ekonomi dari penghuninya. Semakin tinggi tingkat penghasilan atau kemakmuran semakin tinggi pula kebutuhan yang diharapkan dari perumahan yang ia tempati dan kebutuhan tertinggi menyangkut jati diri atau prestise seseorang. Tuntutan kebutuhan atau preferensi seseorang terhadap rumahnya akan selalu berubah sesuai dengan kondisi sosial dan ekonominya ${ }^{3)}$. Akan tetapi hal ini sangat tergantung pada latar belakang dan profil setiap orang.

\section{METODE}

Penelitian ini melihat preferensi masyarakat Kabupaten Bekasi terhadap atribut desain dalam rumah tinggal. Penelitian ini menggunakan metode kuantitatif dengan pertanyaan kuesioner. Sejumlah 150 responden yang tersebar di berbagai lokasi diwawancara secara acak. Metode analisis yang dilakukan adalah melihat frekuensi dan nilai rata-rata atribut desain yang dipilih oleh responden.

Model pertanyaan berupa kuesioner dengan pertanyaan tertutup meliputi profil responden dan preferensi dalam bentuk skala likert ${ }^{4)}$ terhadap atribut desain bangunan yaitu posisi atau layout ruangan, luas setiap ruangan dan jumlah ruangan ${ }^{4)}$ ). Posisi dan layout ruangan terbagi atas ruang tamu, kamar tidur, kamar mandi dan dapur. Luas ruangan yang ditanyakan preferensinya adalah luas ruang tamu, kamar tidur, kamar mandi, dapur, halaman dan carport.

\section{PEMBAHASAN DAN DISKUSI}

Profil 150 responden masyarakat Kabupaten Bekasi yang disurvei secara acak menunjukkan bahwa sebagian besar memiliki pekerjaan karyawan swasta $43 \%$ dan wiraswasta $40 \%$. Pekerjaan lainnya adalah Ibu rumah tangga, guru dan PNS. Komposisi terbesar pendapatan kelompok responden ini berada di angkat pendapatan Rp3.100.000 hingga Rp5.000.000 per bulan, atau kelompok masyarakat berpendapatan kecil menengah dengan sebagian responden memiliki tingkat pendidikan terakhir SMA.

Hunian yang ditinggali oleh responden sebagian besar merupakan hunian milik sendiri. Sejumlah $50 \%$ responden memiliki rumah yang dirancang dan dibangun oleh pemilik sendiri sedangkan $30 \%$ responden membeli rumah baru dari developer dengan desain yang sudah ada. Jumlah ini menunjukkan bahwa 30\% tidak memiliki keleluasaan dalam mendesain bangunannya. Responden yang membangun sendiri bangunannya juga tidak berkonsultasi dengan tenaga profesional perancang dan pembangun. 
Profil masyarakat responden menunjukkan perkiraan bahwa kemampuan ekonomi masyarakat dalam memilih desain yang leluasa sesuai dengan kemampuannya menjadi terbatas. Kelompok masyarakat ini mendominasi masyarakat Kabupaten Bekasi yang tidak menggunakan jasa arsitek sebagai perancang bangunan profesional terlebih mempertimbangkan atribut desain bangunan rumah tinggalnya secara sadar.

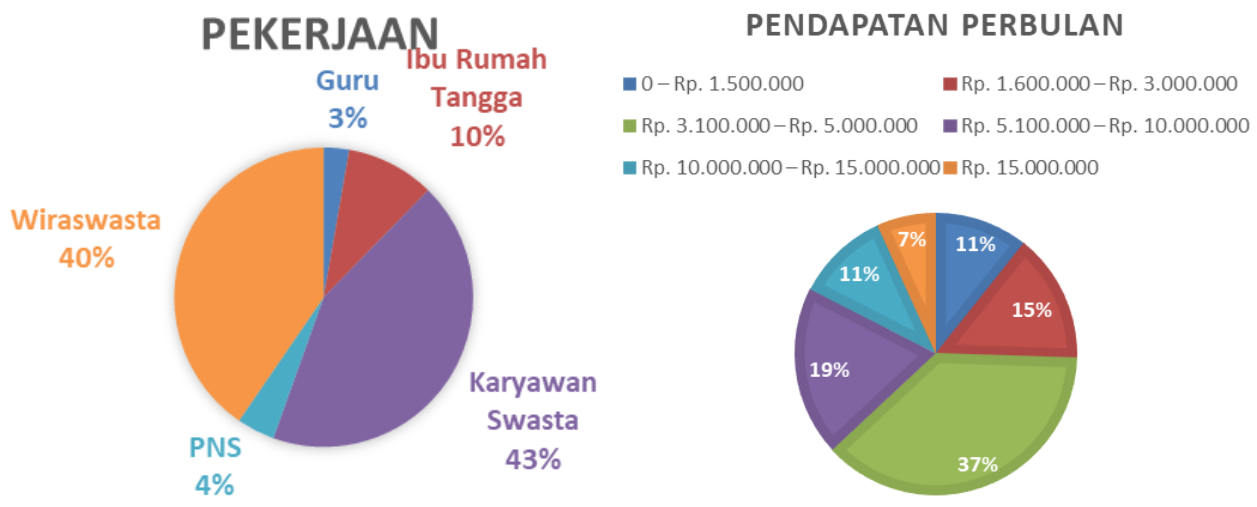

PENDIDIKAN TERAKHIR PEMBANGUNAN RUMAH TINGGAL SAAT INI

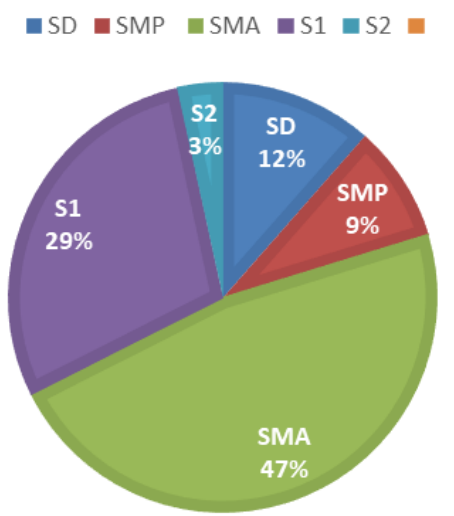

- Desain dan bangun sendiri

- Desain dan bangun dibantu arsitek dan kontraktor

Membeli rumah bekas di perumahan non developer

- Membeli rumah bekas di perumahan developer

Membeli rumah baru dari developer

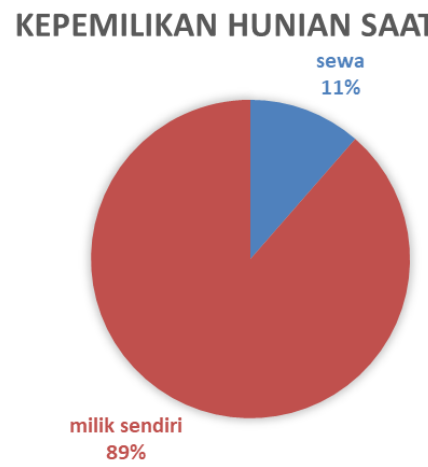

Gambar 1. Profil 150 responden masyarakat Kabupaten Bekasi 
Tabel 1. Nilai rata-rata skala prioritas atribut desain

\begin{tabular}{lr}
\hline Nilai Rata-rata Skala Prioritas \\
\hline Posisi ruang & 4.19 \\
\hline Jumlah Ruangan & 3.78 \\
\hline Luas ruangan & 3.56 \\
\hline
\end{tabular}

Penilaian didasarkan pada skala likert skala 1 hingga 5 dimulai dari keputusan atribut yang paling tidak penting (nilai 1) hingga atribut paling penting (nilai 5). Berdasarkan hasil survei yang dilakukan terhadap 150 responden masyarakat Kabupaten Bekasi, ditemukan bahwa masyarakat memilih posisi ruang dalam bangunan sebagai yang atribut yang penting. Prioritas selanjutnya adalah jumlah ruangan dengan nilai 3.78 yaitu ragu-ragu akan tetapi cenderung penting diikuti luas ruangan dan 3.35 yaitu ragu-ragu.

Tabel 2. Nilai rata-rata skala prioritas atribut layout ruang

\begin{tabular}{lc}
\hline Nilai Rata-rata Skala Prioritas Atribut Layout Ruang \\
\hline Kamar tidur & 4.35 \\
\hline Kamar mandi & 4.23 \\
\hline Ruang tamu & 4.11 \\
\hline Dapur & 4.07 \\
\hline
\end{tabular}

Posisi ruang bangunan rumah tinggal minimal yaitu kamar tidur, kamar mandi, ruang tamu dan dapur secara berurutan merupakan prioritas responden untuk ditempatkan di lokasi terbaik menurut preferensinya masing-masing. Skala prioritas ini menunjukkan bahwa posisi kamar tidur merupakan pertimbangan terpenting dalam layout rumah.

Tabel 3. Nilai rata-rata skala prioritas atribut jumlah ruang

\begin{tabular}{lc}
\hline Nilai Rata-rata Skala Prioritas Atribut Jumlah Ruang \\
\hline Kamar tidur & 4.00 \\
\hline Kamar mandi & 3.55 \\
\hline
\end{tabular}

Untuk ruang dalam bangunan rumah tinggal sederhana yang kemungkinan memiliki jumlah lebih dari satu adalah kamar tidur dan kamar mandi. Responden menyatakan bahwa jumlah kamar tidur menjadi pertimbangan utama dalam desain bangunan rumah tinggal dengan kecenderungan keinginan untuk memiliki lebih dari satu.

Tabel 4. Nilai rata-rata skala prioritas atribut luas ruang

\begin{tabular}{lc}
\hline Nilai Rata-rata Skala Prioritas Atribut Luas Ruang \\
\hline Kamar tidur & 3.75 \\
\hline Ruang tamu & 3.50 \\
\hline Kamar mandi & 3.36 \\
\hline Dapur & 3.36 \\
\hline
\end{tabular}

Penilaian responden terhadap prioritas luas ruangan menunjukkan bahwa luas kamar tidur cenderung dianggap lebih penting daripada luasan ruang lainnya. Prioritas ini diikuti luasan ruang tamu, kamar mandi dan dapur. 


\section{KESIMPULAN}

Penelitian ini menemukan bahwa posisi dan layout ruangan merupakan hal penting bagi masyarakat dalam bangunan rumah tinggalnya. Hal ini dapat membantu perancang untuk melihat atribut ini lebih utama dibandingkan atribut lain. Jika posisi ruangan dianggap baik, maka ruangan yang luas dan banyak tidak selalu menjadi prioritas. Walaupun demikian, atribut desain lain yaitu jumlah ruangan menunjukkan bahwa perancang memiliki kesempatan untuk mendesain ruang-ruang open layout, fungsi campur atau serba guna. Dari penelitian ini juga ditemukan bahwa fungsi kamar tidur menjadi prioritas responden, baik layout, luas dan jumlahnya. Untuk perancang pada kelompok masyarakat ini disarankan agar mengutamakan desain kamar tidur pada perancangan rumah tinggal. Penelitian ini diharapkan dapat menjadi salah satu landasan para perancang dalam mendesain bangunan rumah tinggal di Kabupaten Bekasi.

\section{UCAPAN TERIMA KASIH}

Peneliti menyampaikan terima kasih pada Yayasan ITSB atas pendanaan penelitian dan juga kepada sivitas akademik ITSB dalam kontribusinya terhadap penelitian ini.

\section{DAFTAR PUSTAKA}

1) Zavei, Sayyed. and Jusan, Mahmud. 2012. Exploring Housing Attributes Selection based on Maslow's Hierarchy of Needs. Procedia - Social and Behavioral Sciences, 42, $311-319$.

2) Bourne, L. S. (1978), Internal Structure of The City - Reading on Space and Envirement, Oxford.

3) Budihardjo. (1998), Sejumlah Masalah Permukiman Kota, Bandung: Alumni.

4) Sugiyono. (2010), Metode Penelitian Kuantitatif Kualitatif dan R\&D, Penerbit CV Alfabeta, Bandung.

5) E. Hofman, J.I.M. Halman. 2006. Variation in Housing Design: Identifying Customer Preferences. Housing Studies 21(6):931-945.

6) Jansen, Sylvia J.T (Ed.) (2011); The Measurement and Analysis of Housing Preference and Choice, Springer Science+Business Media B.V, New York. 